\title{
Intracellular and Extracellular Cryoprotectants in Plant Cryopreservation
}

\author{
Ana Beatryz Suzuki Prenzier* and Mauren Sorace \\ Department of Agronomy, Estate University of Londrina, Brazil
}

Submission: March 28, 2019; Published: May 02, 2019

"Corresponding author: Ana Beatryz Suzuki Prenzier, Department of Agronomy, Estate University of Londrina, Brazil

\begin{abstract}
Due to the constant extractivism and changes in the environment, destruction of the habitats of orchids, many species have been extinct, and some others are on a near extinction list. Some species have economic importance, such as vanilla, and others with medicinal properties and some with ornamental value, due to the beauty of its flowers and variety of species, being used in the landscaping. An alternative for the preservation of these species would be through the germplasm bank. Cryopreservation in liquid nitrogen is a widely studied and diffused method in several areas. Several protocols are studied with the purpose of reducing the rate of deterioration after these storage procedures and thus increasing the storage time of the seeds with quality. Therefore, this work aims to present intra and extracellular cryoprotectants found in the literature for cryopreservation of orchids. However, in order to obtain quality materials, the type and type of cryopreserved material and storage time must be considered.
\end{abstract}

Keywords: Germplasm; Cryopreservation; Agriculture; Dehydration techniques

\section{Introduction}

Cryopreservation is a very important method and has been increasingly used in order to preserve plants that are in danger of extinction due to the destruction of their natural habitats with the advancement of agriculture and extractivism. It is a conservation process in which the biological material subjected to ultra-low temperatures using liquid nitrogen $\left(-196^{\circ} \mathrm{C}\right)$.

Germplasm banks are important tools, the simplest form of conservation and maintenance of genetic material. However, for the structures to be recovered after cryopreservation, the addition of cryoprotective substances is necessary. cryoprotectants are classified according to [1] as penetrating (intracellular) and nonpenetrating (extracellular).

The protocols should cover seed collection and disinfection procedures, dehydration techniques and ideal water contents for each species, ways to protect the cells against injury, freezing and thawing techniques, seed germination until acclimatization and seedling production.

In view of this, the use of cryoprotectants is necessary for the protection of cellular structures, especially of the membranes, in order to be successful at the end of the cryogenic process. The objective of this work was to present intra and extracellular cryoprotectants found in the literature for cryopreservation of orchids.

\section{Development}

Cryopreservation in liquid nitrogen is a potentially studied method to reduce the rate of deterioration, thereby increasing seed storage time, ensuring the preservation of plant genetic sources, and reducing costs and loss of viability. Damage to cell membranes due to dehydration and increased solute concentration is responsible in addition to the formation of ice crystals, disruption of membranes and, until death of the cell [2]. Emphasizes that the thawing should also be conducted in a judicious way avoiding to the maximum the conditions for the formation of the crystals in the cellular interior. The survival rates of explants after freezing are mainly related to physiology, water content in cells and the use of cryoprotectants [3].

In view of this, the use of cryoprotectants is necessary for the protection of cellular structures, especially the membranes, in order to be successful at the end of the cryogenic process [4]. In the literature there are several types of cryoprotectants used and are divided into intracellular and extracellular.

Intracellular cryoprotectants are organic solutes responsible for protecting the organelles from cells during cooling. They are molecules with low molecular weight and in this way can cross the cell membranes with relative ease.

The mechanism of action according to [5] are based on structures that promote hydrogen bonds with water molecules. 
These bonds change the orientation of the water molecule in the ice crystals, creating a less harmful environment for the cells. The most commonly used are ethylene glycol, propylene glycol, dimethyl sulfoxide (DMSO), glycerol, methanol and ethanol [6].

The mechanism of action of non-penetrating cryoprotectants is based on the protection of the cells against the osmotic effects during the freezing process, promoting a hypertonic medium that induces water to escape from the cells leading to dehydration, that is, they act in the extracellular environment, thus reducing the possibility of intracellular ice crystal formation. Extracellular cryoprotectants are macromolecules and sugars, proteins, lipids and some amino acids, with functions to reduce the formation of ice, allow dehydration of cells and protect the cell membrane, have high molecular weight cannot penetrate the cells. The most used are sucrose, glucose, lactose, trehalose, polyvinylpyrrolidone (PVP) and mannitol $[7,8]$. Cryoprotectants in high concentrations can cause toxicity to the cells causing irreversible damage. The effects of toxicity can be minimized through brief exposure to cryoprotectants or through rapid cooling [9].

\section{Conclusion}

Cryoprotectants are used to prevent the formation of ice crystals during freezing, and the concentration, exposure time and type of material to be cryopreserved must be checked before choosing the most suitable methodology to be used.

\section{References}

1. Mazur P (1980) Fundamental aspects of the freezing of cells, with emphasis on mammalian ova and embryos. In: International Congress Animal Reproduction and Artificial Insemination. pp. 99-114.

2. Silveira AAC (2015) Criopreservação de ápices caulinares e micropropagação em condições heterotróficas e mixotróficas de Eugenia dysenterica (Mart.) DC. 74 f. Dissertação (Genética e Melhoramento de Plantas) - Escola de Agronomia, Universidade Federal de Goiás, Goiânia.

3. Benson EE, Johnston J, Muthusamy J, Harding K (2008) Physical and engineering perspectives of in vitro plant cryopreservation. Plant tissue culture engineering 6: 441-476.

4. Vieira MLC (2000) Conservação de germoplasma in vitro. Biotecnologia Ciência \& Desenvolvimento 3(14): 18-20.

5. Dalimata AM, Graham JK (1997) Criopreservation of rabbit spermatozoa using acetamide in combination with trehalose and methyl cellulose. Theriogenology 48(5): 831-841.

6. Neves MF, Pinto MJA (2015) Mapeamento e Quantificação da Cadeia Produtiva de Flores e Plantas Ornamentais no Brasil. São Paulo: OCESP. pp. 132.

7. Niemann H (1991) Cryopreservation of ova and embryos from livestock: current status and research needs. Theriogenology 35(1): 109124.

8. Denniston RS, Micheket S, Godke RA (2000) Principles of cryopreservation. In: Tiersch TR, Mazik PM (Eds.), Cryopreservation in aquatic species. World Aquaculture Society 1: 59-74.

9. Vajta G, Holm P, Kuwayama M, Booth PJ, Jacobsen H, et al. (1998) Open pulled straw (OPS) vitrification: A new way to reduce cryoinjuries of bovine ova and embryos. Mol Reprod Dev 51(1): 53-58.

Your next Submission with Juniper Publishers
will reach you the below assets
- Quality Editorial service
- Swift Peer Review
- Reprints availability
- E-prints Service
- Manuscript Podcast for convenient understanding
- Global attainment for your research
- Manuscript accessibility in different formats
( Pdf, E-pub, Full Text, Audio)
- Unceasing customer service
Track the below URL for one-step submission
https://juniperpublishers.com/online-submission.php

